\title{
The Rockwell Co-operative Society and the Iowa Farmers' Elevator Movement, 1870-1920
}

\author{
PHILIP J. NELSON
}

AMERICAN AGRICULTURE expanded dramatically after the Civil War. Much of the growth occurred in the Midwest as it became the nation's granary. Changing circumstances, such as settlement of the western Corn Belt, mechanization of agriculture, and the growth of railroads, transformed farming from a partially subsistence or local marketing activity into one with connections to regional, national, and even international markets. Farmers faced situations and problems seldom encountered in a less commercialized antebellum agriculture. One of the main problems that bedeviled farmers was how to market the ever growing supply of grain at a fair price.

Many agriculturalists believed they had found a solution to this perennial problem in cooperative elevator societies. For Iowans in the late nineteenth century, the model on which they drew was the cooperative elevator in the Cerro Gordo County town of Rockwell. That society, founded in 1889, became the first continuously successful one of its kind in the United States. In fact, from its position of leadership in the farmers' elevator movement, the Co-operative Farmers' Society of Rockwell played a significant role in the agricultural marketing crises of the late nineteenth century and fought many of the poignant battles ensuing from the rise of the cooperative way. The movement to establish farmers' elevators continued the tradition of farm protest, cooperation, and self-help initiated by the Grange

THE ANNALS OF IOWA 54 (Winter 1995). CThe State Historical Society of Iowa, 1995. 
and the Farmers' Alliance, but remained organizationally distinct from those earlier groups, as well as from later groups stressing cooperatives, such as the Farmers Union and the American Society of Equity. ${ }^{1}$

PREDATING THE ROCKWELL EXAMPLE by twenty years, the initial establishment of farmers' elevators in Iowa was influenced by several factors. High wartime prices for grain had increased agricultural production and raised rural expectations. After the Civil War, prices fell and currency depreciated. Farmers expressed increasing dissatisfaction with private elevators and railroad rates and operations. Moreover, for some towns newly reached by the railroads, capital for elevator construction was not available or forthcoming from either local capitalists or outside investors. In some such cases, farmers rapidly organized cooperative associations not only to provide an outlet for their grain, but also to avoid the growing influence of middlemen in the grain trade.

Many of the farmers' elevators of the nineteenth century were associated with the emerging farmers' organizations. However, unaffiliated local groups of farmers founded the earliest grain handling facilities in Iowa. Undoubtedly, a number of these grain loading arrangements were ad hoc "scoop shovel" operations, where farmers transferred grain directly from wagons to rail cars. But fixed elevator or warehouse buildings soon became the norm. The first incorporated farmers' elevator was constructed at the Poweshiek County town of Brooklyn in 1869. ${ }^{2}$

1. Percy W. Bidwell and John I. Falconer, History of Agriculture in the Northern United States, 1860-1920 (Gloucester, MA, 1941). For an authoritative treatment of the cooperative movement, see Joseph G. Knapp, The Rise of American Cooperative Enterprise: 1620-1920 (Danville, IL, 1969). See also Lawrence Goodwyn, Democratic Promise: The Populist Moment in America (New York, 1976); Robert C. McMath Jr., American Populism: A Social History, 1877-1898 (New York, 1993); Jeffrey Ostler, Prairie Populism: The Fate of Agrarian Radicalism in Kansas, Nebraska, and lowa, 1880-1892 (Lawrence, KS, 1993); and H. Roger Grant, SelfHelp in the 1890s Depression (Ames, 1983).

2. The first recorded farmers' elevator in Iowa was founded in 1867 in Blairstown. See E. G. Nourse, "Fifty Years of Farmers' Elevators in Iowa," Iowa Agricultural Experiment Station Bulletin 211 (Ames, 1923), 236. See also T. M. Deal, "The Farmers' Elevator Movement in Iowa" (M.A. thesis, Iowa State College, 1922). 
As the Patrons of Husbandry, commonly known as the Grange, grew rapidly in the Midwest after 1868, it became the single most important organizer of the farmers' elevator movement. Yet the Grange's influence in Iowa was ephemeral, peaking in 1874 with 1,999 locals, and thereafter declining precipitously to insignificance by the $1880 \mathrm{~s}$. With the return of better commodity prices and the reluctance of the National Grange to take an activist national political stand, support melted away in Iowa, and no new farmers' elevators were begun from 1878 to 1886 . Poor management, unfulfilled expectations, and failure to follow true cooperative procedures undercut support for Grange-backed elevators. From then until the mid-1890s, farmers turned more to the Northern Farmers' Alliance, but it was never as popular in Iowa as the Grange had been. Moreover, the Alliance never associated itself in any substantial way with the elevator movement in Iowa, as it did in Minnesota and the Plains states. ${ }^{3}$

Historians largely agree on the reasons for the lack of a statewide cooperative movement in Iowa. Successful passage of the Granger laws in 1889 by the Iowa legislature and cooption by traditional political parties undercut growing farmer radicalism. As Jeffrey Ostler observes, "Party elites quickly regained dominance, and the party system easily absorbed Alliance leaders. Farmers continued to have some political options, but the boundaries of permissible actions were defined from above." Therefore, farmers' elevators spread slowly, relying largely on resources and expertise available in their own

3. Myrtle Beinhauer, "Development of the Grange in Iowa, 1868-1930," Annals of Iowa 34 (1959), 597-618; Nourse, "Fifty Years of Farmers' Elevators," 237-45; Knapp, Rise of American Cooperative Enterprise, 74-75. The Grange controlled 33 percent of grain elevators and warehouses in Iowa and shipped 5 million bushels to Chicago in 1873, according to D. Sven Nordin, Rich Harvest: $A$ History of the Grange, 1867-1900 (Jackson MS, 1974), 150. See also Solon Justus Buck, The Granger Movement: A Study of Agricultural Organization and Its Political, Economic and Social Manifestations, 1870-1880 (Cambridge, MA, 1913), 260-64. For an intellectual history of the Grange, see Thomas A. Woods, Knights of the Plow: Oliver H. Kelley and the Origins of the Grange in Republican Ideology (Ames, 1991), 81-83. The Farmers' Alliance did engage in cooperative activity in Iowa, but rarely did it start elevators. See Deal, "Farmers' Elevator Movement," 35. 
local communities. By the late 1880 s, independent Iowa cooperative elevators organized mainly in a few north central and northwestern locales. The establishment of farmers' companies during that period thus symbolized a turn away from the social and educational goals of the Grange and the politically tinged objectives of the Alliance toward a more concentrated focus on local organization for cooperative economic ends as one of the few remaining alternative courses of action. ${ }^{4}$

Even as grain production soared with the draining of the prairie "pothole" area of north central lowa, and railroads pushed spur and feeder lines into almost every town and village, farmers came to believe that market competition diminished year after year. Grain growers charged that free, competitive local markets were being replaced by semimonopolistic bidding controlled by line elevators and aided by the railroads. During those years, control of grain-buying facilities began passing to what were termed "line houses," that is, grain companies owning more than one elevator. Some elevators were owned outright by the railroads that served them. Whether railroad-owned or not, line houses were often financed by eastern capital. Many local or independent elevators also existed, but in some locales their grain bids were often identical to those of the line houses and other independents. By the end of the 1880 s, then, for many country stations competition was practically nonexistent - or so many agriculturalists believed. ${ }^{5}$

IN 1886 farmers again began to establish cooperative elevators in Iowa. Droughts and lower commodity prices aggravated agrarians' suspicions of collusion and price-fixing by the so-

4. Ostler, Prairie Populism, 174; Nourse, "Fifty Years of Farmers' Elevators," 242. For general accounts of American agricultural history that address the notion of cooperation, see Theodore Saloutos and John D. Hicks, Agricultural Discontent in the Middle West, 1900-1939 (Lincoln, NE, 1951); Murray R. Benedict, Farm Policies of the United States, 1790-1950 (New York, 1953); and Gilbert Fite, American Farmers: The New Minority (Bloomington, IN, 1981). For the diminution of farmer militancy in lowa politics, see Goodwyn, Democratic Promise; McMath, American Populism; and Ostler, Prairie Populism.

5. Joseph B. Kenkel, "The Cooperative Elevator Movement" (Ph.D. diss., Catholic University of America, 1922); Deal, "Farmers' Elevator Movement," 15-18. 
called trusts. The farmers' elevators founded at that time began to include truly cooperative principles in their articles of incorporation. The elevator founded at the Cerro Gordo County town of Swaledale in 1887 became a model for the application of cooperative provisions to farmers' elevators. The Swaledale elevator, like most Grange and Alliance cooperatives, based its cooperative practices on the Rochdale Principles, which had evolved among a group of English weavers in 1844 called the Rochdale Pioneers. The ten Rochdale Principles included open membership, "one man, one vote," cash trading, limited stock ownership, and the distribution of profits on the basis of patronage. ${ }^{6}$

Several farmers' elevators, including the one at Swaledale, failed after only a few years, due mainly to poor management and undercapitalization. But the cooperative society at Rockwell weathered boom-and-bust cycles and cutthroat competition to become the oldest continuously operating cooperative elevator in the United States. In his memoirs, Rockwell Society leader Reuben Holman remembered that a handful of area farmers, led by William Barragy, agitated for and organized the cooperative over a period of about eighteen months. In the fall of 1888, initially meeting by lantern light in a granary on J. B. McGaheran's farm near Rockwell, that group was fortunate enough early on to bring into their circle men who possessed experience both in business and in the cooperative movement. For example, Barragy secured the participation of Norman Densmore, who had been involved in railroad construction and also was a teacher. Building on experiences in the Wisconsin Alliance, Densmore, as the society's first president, was instrumental in guiding it through early troubles.?

6. Nourse, "Fifty Years of Farmers' Elevators," 242-43; Reuben A. Holman, Forty Years of Cooperation (Rockwell, 1931), 52; Nordin, Rich Harvest, 149. E. P. Roy, Cooperatives Today and Tomorrow (Danville, IL, 1969), 201, lists the five other Rochdale Principles: political and religious neutrality, no assumption of unusual risks, limited interest on stock and goods sold at regular retail prices, membership education, and services at cost.

7. Deal, "Farmers' Elevator Movement," 216-28; Holman, Forty Years of Cooperation, 1, 2, 45-57. 
In general, most of the initial organizing group were either experienced businessmen or successful farmers. Matthias and Andrew Johnson, for example, farmed nine hundred acres with thirty horses. Supporters of the soon-to-be Co-operative Farmers' Society of Rockwell came to the cooperative movement in varied ways. Reuben Holman's father had been in the Grange, and passed along the spirit of cooperation to his son, who later became prominent in the cóoperative movement both at the local and the state level. John McGaheran, too, brought to the society an existing fervent faith in cooperative action. He treated the society as his personal crusade, and during troubled economic times he selflessly left in the cooperative's account funds that were payable to him. McGaheran's fellow Irishman Thomas McManus did not bring the cooperative spirit with him when he emigrated from Ireland in 1862 and ultimately settled on a farm twelve miles from Rockwell in 1871. His "conversion" to cooperation occurred as he took a load of wheat to market in 1888. He drove a total of thirty-four miles, contacted three different elevators, and received identical bids from each. That experience convinced him of at least a local lack of competition within the grain marketing system. ${ }^{8}$

The Co-operative Farmers' Society of Rockwell first met on January 30, 1889. The society adopted the "Swaledale" articles of incorporation and amended the agreement with a limitation of one vote per member and a maximum society indebtedness of five thousand dollars. One hundred members bought shares costing ten dollars each, with the beginning capitalization reaching one thousand dollars. Committees were formed, ranging from one on bylaws to another charged with finding a suitable location for the elevator. More than one hundred people from the Rockwell area attended the incorporation of the society on March 2, 1889, and unanimously elected the officers. At the first board meeting on March 9, the directors appointed Thomas Chappell as the society's agent; out of his salary of one thousand dollars per year, he was to hire his own help. The board also sought estimates on the cost of constructing an elevator. ${ }^{9}$

8. Holman, Forty Years of Cooperation, 52-56.

9. Ibid., 6-7. 
Two private elevators already existed in Rockwell: the first built by J. B. Piersol, the second owned by George Felthouse, who had been buying wheat and oats since 1875 . The society incurred opposition in finding an elevator site, but not from the Iowa Central Railroad, a regional carrier serving Rockwell and seeking additional traffic. Many local people were convinced that a third elevator would ruin the local economy, or that one or two of the elevators would fail as some in the past had done in other communities. The society's board continued to meet every week for some months. Perhaps persuaded by the directors' determination and perseverance, the firm of Inman and Piersol offered to sell its elevator to the cooperative for two thousand dollars. The society accepted the offer, and on April 1 it began buying grain. Toward this end, a Mason City banker loaned one thousand dollars without interest for one year to get the business started. ${ }^{10}$

IMMEDIATELY, the society faced opposition in the form of overbidding from the other elevator in town. The competitor first raised the price it offered on grain by four cents per bushel to match the farmers' elevator's price, then raised its price another four cents per bushel. Predictably, cooperative members began to sell their grain to the competing local elevator. The society instantly recognized the threat this posed to its viability, because the leaders knew of previous farmers' cooperatives killed by the overbidding strategy. The cooperative's board scheduled emergency meetings to formulate a response. During the second of those meetings, president Densmore proposed a new bylaw providing for the establishment of a maintenance fee to be charged against members who chose to sell grain outside of the cooperative. The fee amounted to one-half cent per bushel, which was the same fee the elevator assessed on grain sold to it by its members. On June 7, 1890,

10. Ibid., 8; Elisabeth Jane Roeder Hitzhusen, The Story of Rockwell, Iowa, 1870-1970 (Rockwell, 1970), 61. The Felthouse elevator had a capacity of 15,000 bushels and passed an average of 135,000 bushels through it annually. Rockwell Tribune, Centennial edition, June 1970. 
the cooperative's board of directors enacted the maintenance clause. ${ }^{11}$

The measure proved its worth almost immediately in the growing struggle with the line houses, which continued their practice of outbidding the farmers' companies. Some cooperatives did fail, but the Rockwell farmers' elevator remained largely unaffected. The society kept to the letter of the bylaw. Members not remitting to the cooperative the one-half cent per bushel maintenance fee on grain sold to competitors would be notified within thirty days of the transaction. If at the end of sixty days the commission was still unpaid, a second notice suspended the member until the debt was made good. In some cases, the monthly board meetings reported suspensions and reinstatements up to nine at a time, but an intense loyalty kept the society's membership level relatively stable. In this "David and Goliath" contest, the upstart Rockwell Co-operative finally prevailed when the line elevators and allied independents temporarily abandoned the conflict against the society in the late 1890s. Most observers, both at the time and later, believed that it was only the extraordinary determination of the farmers and their willingness to impose upon themselves the maintenance fee that enabled the farmers' elevator company to live through its struggle. ${ }^{12}$

Most line companies and many independent grain dealers opposed the market entry of farmers' cooperatives on principle, but especially in locales where they already had an elevator in operation. Both the Rockwell Society and its opposition quickly realized that the maintenance or protection clause was the key to the success of farmers' cooperatives in a hostile business climate. The benefit to farmers' elevators was summarized by Oscar Refsell, an early observer of the cooperative movement: "Under this arrangement the farmers' company would not be tempted greatly to bid a high price against its competitor when doing so would involve a loss. Neither could the company be

11. Holman, Forty Years of Cooperation, 7-9; Knapp, Rise of American Cooperative Enterprise, 76.

12. Knapp, Rise of American Cooperative Enterprise, 76; Holman, Forty Years of Cooperation, 9; Oscar Refsell, "The Farmers' Elevator Movement," Journal of Political Economy 22 (1914), 891-92. 
ruined by the high price paid by a competitor, even though these prices would prevent the farmers' company from procuring the grain. The income would still be the same as before, while its expenses would be slightly decreased." The line houses characterized the maintenance clause as a "penalty clause," and did everything in their power to stymie farmers' elevators. In addition to the overbidding tactic, they fixed prices in areas where they had monopolistic control and built or leased elevators in direct competition with farmers' elevators where they did not. They also elicited railroad opposition to farmers' elevators' efforts to secure sites for their operations and to move the grain they purchased. ${ }^{13}$

Railroads, the very instruments of much of the farmers' prosperity, sometimes became their worst enemies. Agriculturalists viewed railroads in a special light; they looked on them as public organizations, because they had been largely subsidized by the government, private industry, farmers, and even whole towns eager for their arrival. But agrarians also tended to see speculators and monopolies everywhere they looked, and vehemently opposed the railroads when they appeared to stand in the way of the elevator movement. In 1902 Rockwell's neighboring town to the southeast, Dougherty, decided to organize a cooperative society, contending that prices there were well below the Rockwell market. The Dougherty society chose former Rockwell member Thomas McManus as its president. However, the Chicago and North Western Railway, which ran through the town, denied the elevator a building site, arguing that two existing elevators were enough. McManus responded by securing the placement of a bill before the Iowa legislature that would have forced railroads to give sites to farmers' elevators. Before the bill came to a vote, the railroad offered a site to the Dougherty cooperative in exchange for the withdrawal of the McManussponsored legislation. ${ }^{14}$

13. Nourse, "Fifty Years of Farmers' Elevators," 244-45; Refsell, "Farmers' Elevator Movement," 891.

14. Woods, Knights of the Plow, 81-83; Rockwell Phonograph, 17 June 1902; Deal, "Farmers' Elevator Movement," 45-46; Holman, Forty Years of Cooperation, 53. In 1913 Iowa did pass a law similar to the one McManus proposed. Laws of lowa (1913), chap. 178. 
A group of farmers at Sloan, Iowa, experienced a similar rebuff from the same railroad. They had shipped a carload of wheat on their own, and had realized a gain of eighteen cents per bushel over the local bid. They then eagerly organized a cooperative elevator to take advantage of increased profits, only to find their site acquisition process stalled for a year. They finally secured a site after pleading directly with the president of the Chicago and North Western Railway. ${ }^{15}$

In their efforts to stymie farmers' elevators, the line houses and independent grain elevators, in conjunction with the railroads, were quite successful in the 1880 s and 1890s. Falling grain prices and the Panic of 1893 also served to undercut the progress of the cooperative movement. Of thirty-four cooperative elevators organized in Iowa since 1886, only fourteen continued to operate in $1900 .^{16}$

Meanwhile, blessed with the protection fee and disciplined management in the person of Thomas Chappell, and later Frank Campbell, the Rockwell Society prospered. By March 2, 1892, members received dividends of ten dollars each. Gross sales for 1898 amounted to $\$ 366,000$, and in 1901 they stood at a little over $\$ 624,000$. By 1909 , the society reported capital worth $\$ 45,000$ and a membership of six hundred. By 1929 , the society had paid out to stockholders excess profits (over and above those returned as patronage dividends) amounting to over $\$ 380$ and thirty new shares of stock per shareholder. The success of the so-called penalty clause made the society and the village of Rockwell (with its approximately five hundred citizens) famous throughout midwestern cooperative circles. Other farmers' elevators in Iowa, Illinois, and nearby states adopted its bylaw, and by 1900 the penalty clause had become a standard operating procedure in many cooperative elevators. ${ }^{17}$

15. Deal, "Farmers' Elevator Movement," 40-41.

16. Ibid., 36.

17. Knapp, Rise of American Cooperative Enterprise, 77; Holman, Forty Years of Cooperation, 15, 30; Thomas McManus, "The Rockwell Co-operative Society," in The History of Cerro Gordo County, Iowa, ed. J. H. Wheeler, 2 vols. (Chicago, 1910), 1:368. For the Illinois farmers' elevator story, see Lawrence Farlow, The Farmers Elevator Movement in Illinois (n.p., 1928). 
SIDELINES to the main grain business were a natural outgrowth of the cooperative enterprise. The society sold supplies, fuel, clothing, building materials, and implements generally from its inception. Indeed, on the first day of business the cooperative sold "coal at $\$ 2$ less per ton and lumber at $\$ 5$ less per thousand feet" than its competition. To its members, the society sold at wholesale cost, plus a small handling fee. As an inducement to membership, it charged nonmembers higher commissions and paid them less for their grain. On machinery, for example, the cooperative applied a 2 percent margin to members and a 10 percent margin to nonmembers. One sideline generated the first recorded discord among members. During the 1904 annual meeting, an argument developed over the sale of clothing, which amounted to a business of five thousand dollars. President Densmore, who did not believe in branching out, questioned the authority of those responsible for such sales. Backers of the mercantile business showed its benefits and downplayed its seriousness by referring to it as a "little business upstairs."18

The society faced outside opposition in almost all lines of merchandise. Early opposition to equipment sales from several out-of-state manufacturers caused the line to be dropped after only a few years. Pressure to discontinue machinery sales also came from local implement dealers and from a state organization, the Iowa Agricultural Implement Dealers' Association, which went so far as to organize a boycott of all implement makers who dared to deal with the society. The Hamilton Brothers of Cedar Rapids actually did make a sale to the Rockwell Co-operative, and promptly faced a resolution of boycott from the association. The association also forced the Morrison Manufacturing Company of Fort Madison to cancel a previously accepted order for two carloads of machinery. Ultimately, the Rockwell Co-operative was unwilling to contest implement sales, mainly because farm equipment was not its main business activity. ${ }^{19}$

18. Nourse, "Fifty Years of Farmers' Elevators," 244. The clothing business was approved, but its capital was limited to $\$ 2,500$. Rockwell Phonograph, $8 \mathrm{March}$ 1904. Unfortunately, none of the editions of the Rockwell newspaper survive for the years prior to 1900, and they are incomplete for the years 1900-1912. 19. Holman, Forty Years of Cooperation, 10; Deal, "Farmers' Elevator Movement," 31-32. 
The society was, however, willing to fight to retain another sideline: lumber. The cooperative entered the lumber business in 1893 by purchasing the yard of Walsh and Zeidler. Later that same year, the Felthouse brothers, owners of a grain storage facility in Rockwell, proposed to sell their elevator and its accompanying lumber yard to the cooperative for $\$ 4,500$. Having just bought a yard, the society refused the offer. The Felthouse brothers then sold their yard to John Paul, a Wisconsin multimillionaire who owned a chain of lumber yards stretching across Minnesota into South Dakota. In a blatant attempt to drive the society out of the lumber business, Paul lowered prices drastically on both lumber and coal in Rockwell. The prices were so low that wagon teams came from near Mason City, a distance of fifteen miles or more, to purchase construction materials and fuel. Reuben Holman asserted that the Rockwell Co-operative withstood the ten-year-long "dumping" strategy by simply refusing to buy from Paul. Ultimately, the society bought him out and built a larger lumber yard on the old site. Evidently the society was satisfied with the lumber business, because it claimed a continuous savings of two dollars per thousand feet over the regular retail price. ${ }^{20}$

THE GRAIN TRADE, however, stirred the most significant opposition to the operation of the Rockwell Society and the other surviving farmers' elevators. The opposition came primarily from the line houses and independent grain dealers. When they were unable to prevent the establishment of farmers' elevators, the grain dealers sought to interfere with the cooperatives' ability to move and market their grain.

In the 1890s a handful of giant Chicago-based terminal elevators expanded to gain control over scores of country elevators positioned along the main trunk railroads, which ran into just about every village and town in the Corn Belt. The growth of these line elevators, in addition to smaller independents, stifled the potential growth in the number of cooperative enterprises. William Baker, the president of the Chicago Board of Trade, 
described the turn-of-the-century terminal elevator system: "The old time open competition of thousands has been superseded by new conditions under which [a] railroad terminating in Chicago is practically controlled by a single buyer. Special rates are made to favored individuals who have the further advantage of elevator control, so that rates charged to the public are rebated to themselves, thus enabling them to out bid or undersell all competitors." 21

In many places in the Midwest, farmers at first welcomed the line houses because they brought capital and higher grain bids. But in the process, many independent companies were either bought or driven out of business. The independents that remained usually fell under the influence of the line companies. Although fewer line houses existed in Iowa than in Minnesota or the Dakotas, they succeeded in organizing a state grain dealers' association in 1900. Thus, they followed in the footsteps of state grain dealers' associations created in both Illinois and Nebraska before the turn of the century. A 1920 Federal Trade Commission report on the grain trade found that the grain dealers' associations were antagonistic to the farmers' elevators and to all "irregular" shippers. As the grain dealers stepped up their actions against nonmembers of the association, "this competition gradually led to various agreements among elevators, especially in the territory west of the Mississippi, with reference to prices, the pooling of purchases at particular stations, and other practices all more or less designed to decrease or eliminate competition." 22

The issue of control of the Iowa grain marketing industry intensified in 1902, when the grain dealers sent a bulletin to all their members listing fifty-eight "unrecognized" shipping firms. By its refusal to recognize cooperatives through the use of the blacklist, the state association in essence began a market war aimed at total elimination of farmers' elevators. By 1903, the grain dealers escalated the struggle by attempting to cut off

21. Deal, "Farmers' Elevator Movement," 36; U.S. Federal Trade Commission, Report of the Federal Trade Commission on the Grain Trade, 7 vols. (Washington, DC, 1920), 2:96.

22. FTC, Report on Grain Trade, 1:83. 
marketing outlets for cooperatives' grain. George Wells, the secretary of the Iowa Grain Dealers' Association (IGDA), sent letters to all grain brokers known to be dealing with farmers' elevators. In one such letter, dated February 17, 1903, Wells advised the Chicago firm of Eschenberg and Dalton not to transact any business with farmers' elevator companies because they "organized for the purpose of agitating local markets." He considered them illegitimate competitors who would put conventional dealers out of business. This thinly veiled warning also contained a list of nine Iowa cooperative elevators with whom business should cease. The Rockwell Society's name appeared on that list. ${ }^{23}$

In 1904 the IGDA began its boycott of Chicago commission firms and grain receivers who continued to buy grain from cooperative elevators. Members of the association began to withhold their grain from the offending brokerage houses, while grain from farmers' elevators began to pile up in warehouses or sit unattended on sidings in Chicago. Only two commission firms - Lowell Hoit \& Company and Eschenberg \& Daltonresisted the boycott. James Dalton of Eschenberg \& Dalton attested to the severe results of the boycott by stating that "Well's [sic] influence even reached outside of Iowa into Minnesota and South Dakota, and he certainly can flatter himself in the fact that he accomplished his purpose." Wells also criticized the Rockwell Society for applying the penalty clause to grain it did not market. As elevators on new rail lines shrank the Rockwell Co-operative's direct marketing area, he charged that the society continued to take a "profit on business they [did] not legitimately earn." ${ }^{24}$

Despite the pressure applied by the IGDA, the commission firm of Lowell Hoit \& Company openly declared its intention to continue to accept grain from farmers' elevators, and even took an activist approach in soliciting business from cooperatives. The IGDA attempted to intensify the pressure on the recalcitrant firm by directing its secretary, George Wells, to send

23. Ibid., 1:87-90; Nourse, "Fifty Years of Farmers' Elevators," 246-47.

24. Nourse, "Fifty Years of Farmers' Elevators," 247; FTC, Report on the Grain Trade, 1:91; Wallaces' Farmer 29 (11 November 1904), 1399. 
a letter to IGDA members urging them to write to the firm, taking a "carrot and stick" approach.

My purpose is to thus place them under sufficient obligation to the members of this Association, so that they will consider it for their best interest to confine their dealings in the future to the firms that are recognized.

Do not raise the question about the Farmers' Elevator Companies in your first letter, but take that up with them later, after having given them some business. Please, keep this matter confidential and advise me of your action and results. ${ }^{25}$

Throughout 1904 the Grain Trust (as it was called by agrarians and others) kept up the boycott on grain commission firms still willing to buy from farmers' elevators. Those brokers who stuck with cooperatives initially lost 95 percent of their normal business. In Iowa the IGDA maintained its pressure on the two Chicago brokerage firms and thirty small farmers' cooperatives by means of the combined efforts of more than five hundred line and independent elevators. Newly established cooperatives suffered the most from the boycott, but even older elevators such as Rockwell's moved less and less grain as well. Finally, in October 1904, two small cooperatives appealed to the Rockwell Society for help. In the interest of self-preservation, the society sent out a call to all parties interested in the creation of a state association of cooperatives. ${ }^{26}$

On November 3, 1904, delegates poured into Rockwell to establish a farmers' organization to counter the power and influence of the IGDA. The delegates represented numerous groups, such as the Nebraska Farmers Union, the Iowa Grange, and 39 cooperative elevators, only 26 of which were formally invited. Two important participants from Illinois-William Stickney, a paid organizer from Lowell Hoit \& Company, and A. J. McCreary, the secretary of the recently created Illinois state cooperative association - provided valuable organizational aid. The result of the meeting was the founding of the Iowa Farmers'

25. George Wells to members of the IGDA, quoted in Kenkel, "Cooperative Elevator Movement," 25.

26. A Brief History of the Farmers' Cooperative Grain Dealers' Association (Eagle Grove, 1914), 1-3; Reuben A. Holman, The Romance of the Farmers Grain Dealers Association of lowa (n.p., 1947), 71. 
Grain Dealers' Association, a state farmers' organization for cooperatives. ${ }^{27}$

Stickney and McCreary went on to assist the growing cooperative movement throughout the Midwest. Working in tandem with the newly formed Iowa Association of Cooperatives, their efforts further stimulated the development of regular bookkeeping methods and supported searches for competent managers. They helped secure elevator sites, explained legal organizational details, and pointed out where equipment for grain handling could be obtained. Without the teaching and missionary efforts of the paid organizers from the commission firms that resisted the boycott, both the brokerage houses and the embryonic farmers' elevator movement might have been ruined. Finally, such efforts, in combination with similar actions in Illinois, helped lift the boycott on both the Illinois and Iowa farmers' elevators. ${ }^{28}$

The Iowa Farmers' Grain Dealers' Association (IFGDA) formally established itself in Fort Dodge, with C. G. Messerole, manager of the Gowrie Co-operative, as its first secretary. Messerole coordinated all the efforts of the association, drawing on a wide network of experienced cooperative men, including Norman Densmore and James H. Brown, both of the Rockwell Society. The Rockwell Co-operative continued to offer strong support for the IFGDA. In 1913, for example, five Rockwell Society members attended the state meeting, and Thomas McManus of Dougherty was elected president. ${ }^{29}$

So successful was the campaign on behalf of farmers' elevators that their number grew from a mere 30 in 1904 to 345 in 1914 , with a total of sixty thousand stockholders. Total grain

27. Holman, Romance of the IFGDA, 71-72; Nourse, "Fifty Years of Farmers' Elevators," 248; Wallaces' Farmer 29 (11 November 1904), 1398. By late December 1904, the Rockwell Co-operative was able to ship seven carloads of corn to eastern markets. Mason City Express Republican, 29 December 1904. The Iowa Grain Dealers' Association represented the "Grain Trust" in Iowa; the opposing farmers' elevator organization was the Iowa Farmers' Grain Dealers' Association.

28. Holman, Romance of the IFGDA, 71-72; Nourse, "Fifty Years of Farmers' Elevators," 248.

29. Holman, Romance of the IFGDA, 73-74; Rockwell Phonograph, 18 February 1913. 
handled stood at over 115 million bushels; total investment amounted to over $\$ 3$ million. The IFGDA claimed a yearly savings for Iowa farmers of $\$ 3.5$ million on grain sales, with other substantial savings realized on secondary merchandise lines. Cooperative observer E. G. Nourse noted,

As they grew in number and influence they became an important factor in securing fairer treatment from the railroads in this matter and also on car supply, losses in transit, and the collection of claims. They were instrumental in improving weighing and grading practices at the terminals and in securing the passage of a fairly good cooperative law in 1915. They worked with similar associations in other important grain states for these purposes and also in supporting the American Cooperative Journal, which became the official organ of the farmers' elevator movement in $1906 .{ }^{30}$

MANY MIDWESTERN FARMERS looked to their local cooperative elevators as allies and friends. Meanwhile, they defined their enemies as eastern corporate interests, which they lumped together under the term "Grain Trust." This "trust" also incurred the wrath of midwestern senators, chief among them Robert La Follette of Wisconsin. In the closing days of the 1906 session of Congress, La Follette obtained a resolution authorizing the Interstate Commerce Commission to investigate charges of monopoly and predatory pricing in the elevator business. The commissioners held hearings in the fall of 1906, stopping at Chicago, Kansas City, Omaha, and other western points. Their last stop, Des Moines, gave them the opportunity to look into the IGDA, about which they had heard a great deal in their western investigations. ${ }^{31}$

Grain men from all over Iowa flocked to the Des Moines hearings, held on October 26, 1906, to witness how the Iowa Grain Dealers would respond to charges of conspiracy to eliminate the independent cooperative elevator movement. J. T. Hiland, Third Vice President of the Chicago, Milwaukee and

30. Holman, Romance of the IFGDA, 73-74; Nourse, "Fifty Years of Farmers' Elevators," 249.

31. Holman, Romance of the IFGDA, 78; Des Moines Register and Leader, 26 October 1906. 
St. Paul Railway (Milwaukee Road), took the witness stand first. After two hours of intense questioning, he gradually revealed a consistent pattern of discrimination against small and cooperative elevator companies. In particular, his testimony showed how his railroad showed extreme favoritism to a certain line elevator in Kansas City, much to the detriment of competing firms. In this case, the Simonds-Shield Grain Company, in return for an annual fee of twenty-five hundred dollars, received various privileges worth twenty thousand dollars, acquired advance knowledge of cuts in freight rates, which allowed it to save thousands of dollars on shipping costs, and secured twenty-five hundred rail cars while other shippers were denied rolling stock. Perhaps not all rail lines engaged in this sort of corruption, but old-time Grangers, Alliance supporters, and Populists must have felt vindicated. ${ }^{32}$

In order to uncover proof of pooling and price fixing on the part of the IGDA, the commission delved into an investigation of the Des Moines Cereal Club. Ostensibly a social club, it appeared to farmers' groups to be the "executive committee" for the Grain Dealers. It allegedly met every week to determine the grain prices to be bid in the near future. Those prices were then supposedly given to Ward G. Case, a Des Moines market consultant, who wrote them on cards and sent them to all members of the association. All of the club's members who testified denied these allegations. But grain broker R. W. Harper of Des Moines, a one-time guest at the club, verified the allegations about price fixing and the use of the price cards. ${ }^{33}$

Given this contradictory testimony, Commissioner F. H. Lane allowed club members who had previously denied price fixing to "amend their testimony." George Wells, the association's secretary, took the stand and stated that he was not involved in that behavior at every meeting. Commissioner Lane suddenly interrupted and brusquely cross-examined Wells.

32. Holman, Romance of the IFGDA, 79-80. For a more positive view of nineteenth-century railroad conduct in Iowa, see H. Roger Grant, "Railroaders and Reformers: The Chicago \& North Western Encounters Grangers and Progressives," Annals of lowa 50 (1991), 772-86.

33. Des Moines Register and Leader, 27 October 1906; Holman, Romance of the IFGDA, 83-84. 
"Didn't you try to mislead the commission on that point?" Mr. Wells said he had not.

"Why did you testify as you did?" continued Commissioner Lane. "Did you not try to create the impression in the commissioner's minds that there was no fixing of prices and that nothing was done to fix prices at those meetings? Didn't you do that?"

Mr. Wells insisted that he had not done so.

"Was not that your distinct effort in answer to that question?" persisted Mr. Lane.

"No sir," replied Mr. Wells.

"Didn't you in every way try to evade and avoid answering the questions of Mr. Marble (the commission's lawyer) put to you at the time, when asked in regard to fixing prices?"

Mr. Wells started to make some explanation when he was dismissed from the stand.

The Des Moines Register and Leader went on to characterize the incident as "sensational in the extreme." After Wells's testimony, the report continued, "information relative to the fixing of prices in unison for the Iowa grain market was extracted from witnesses without much difficulty. ${ }^{\prime 34}$

Accused of formulating and distributing price-fixing cards to members of the IGDA, Ward Case admitted little. Reporters observed that he answered evasively and without remembering much of substance. Case claimed that his daily price cardsknown as Case cards in the Iowa grain trade-were merely advisory, not mandatory. Many witnesses, however, contradicted Case's testimony; they stated that the Case cards were generally used as the standard price basis, especially at stations where there was more than one elevator. ${ }^{35}$

Other witnesses testified to the existence of extensive pooling arrangements whereby all the non-farmers' elevators in a given territory agreed to buy a certain amount of grain. Any elevator buying above that level paid a penalty of two or three cents per bushel on the excess. A grain pool formed in Humboldt in 1894 by the Peavey Elevator Company, the Great Western Elevator Company, and Hensen and Taylor lasted for seven

34. Des Moines Register and Leader, 27 October 1906.

35. Ibid; Deal, "Farmers' Elevator Movement," 50-51. 
years and threatened the existence of the farmers' elevator in Badger. Evidence taken by the Interstate Commerce Commission indicated widespread use of pooling, especially as a retaliatory measure, by the IGDA. ${ }^{36}$

For the Rockwell Society, these indictments simply confirmed what its members had argued since its inception. An incident from the society's own history demonstrated the lengths to which its opposition went in order to discover its vulnerabilities. Ten years after the founding of the Rockwell farmers' elevator, leaders of midwestern railroad and grain businesses assembled in Mason City. The conference invited Frank Campbell, the society's manager, ostensibly because he had built the cooperative into what they considered one of the best shippers on the Iowa Central Line. Campbell attended the gathering, but quickly discerned the ulterior motive behind his invitation. The conference organizers attempted to win him to their side with offers of a better position and a much higher salary. When he refused, they promised him an elevator of his own and guaranteed profits. He again declined, prompting threats to the Rockwell Society, to which Campbell replied, "Come on. I'm ready for you. ${ }^{i 37}$

THE IMMEDIATE PRESSURE of boycotts, price fixing, and pooling eased somewhat for the farmers' elevators after the public relations fiasco suffered by the IGDA at the hands of the Interstate Commerce Commission. The Des Moines Register and Leader portrayed the IGDA as having been engaged in a deliberate attempt to crush farmers' elevators by restricting their terminal markets, creating pooling arrangements, fixing prices through the actions of Ward Case, legitimizing the Case cards by proclamation of the Des Moines Cereal Club, and forcing independents into pooling consortia. Yet in an industry where the regular profit margin was four to five cents on most grains, some line elevators with monopoly holds on their territories still

36. Deal, "Farmers' Elevator Movement," 51.

37. Holman, Romance of the IFGDA 19. Holman was somewhat given to hyperbole, but evidently the original directors and employees were highly principled and loyal people, completely devoted to the cooperative. 
realized margins on rye, for example, of as much as nine to thirteen cents. ${ }^{38}$

The same circumstances that originally called farmers' elevators into existence continued to hamper agrarians' efforts to obtain an equitable marketplace. The IFGDA strenuously attempted to spread the gospel of the protection clause to new and old farmers' elevators alike. Such efforts began to pay off, as 131 farmers' elevators were organized in the years 1905-1907 alone. Speaking before the 1908 IFGDA convention, Ben Hathaway, an association director, claimed that "the only thing that saved us when everything else was gone was the one cent protection clause." The regular line and independent dealers knew this as well, and took every opportunity to attack and annul the maintenance clause. During the Des Moines ICC hearing, George Wells impugned the protection clause, calling it a restraint of trade and an unfair advantage. Commissioner Lane, however, showed his approval of the clause. "The farmers have a right to protect their interests if they so desire, by least possible expense," he said. "They surely have a right to market their products on a co-operative plan if they wish, and pay the expenses of running their business as they see fit." ${ }^{139}$

Having failed in their offensive against the protection clause in Iowa, agents of the grain dealers' associations filed suit in 1911 against The Farmers' Grain Company, an Illinois cooperative. Before the circuit court of Monticello, Illinois, the dealers argued that the penalty clause was not in the public interest and implied a restraint of trade. The judge, however, found for the farmers' company, noting that the protection clause "is not in restraint of trade, because it has not been against public interest. A competitor is a middleman and not the public." ${ }^{\prime 40}$

Yet only two years later, in 1913, the Iowa Supreme Court ruled against the clause in a case involving the Decorah Farmers' Co-operative Society, a livestock shipping association. The court ordered the cooperative not to enforce the protection

38. Des Moines Register and Leader, 27 October 1906.

39. Nourse, "Fifty Years of Farmers' Elevators," 250; American Cooperative Journal 4 (March 1908), 78; Commissioner Lane quoted in Holman, Romance, 85.

40. Kenkel, "Cooperative Elevator Movement," 27. 
clause because it was a restraint of trade. Although an estimated 80 to 90 percent of all cooperatives retained the maintenance clause in their bylaws, few subsequently deemed it necessary to enforce it. One active cooperator, Thomas McManus, even believed the clause was no longer needed.

If it is illegal and a crime, I plead guilty to the charges, as I happened to be one of the men at Rockwell twenty-four years ago who framed and incorporated that clause in our by-laws, which seemed to us the only remedy to save us from unscrupulous and unfair competition. I think, however, whether the ruling is just or otherwise, the "penalty clause" has served its mission, and while it saved hundreds of elevator companies from disaster and disruption, it is needed no more, as the farmers are becoming more and more educated in their loyalty and devotion to their own elevators. ${ }^{41}$

Other longtime cooperative enthusiasts still argued vehemently for enforcement of the protection clause, but most members realized that the lessons of the past had been well learned.

The period from 1904 to 1921 witnessed explosive growth and a new stability for farmers' elevators. Five hundred thirtyone farmers' elevators were founded in this period, with only fifty failing; of that number, ten were reestablished in a few years. Of the 1,668 elevators in Iowa as of 1918, 511 (33 percent) were farmer-owned cooperatives; they handled 42 percent of Iowa's grain shipments. By the 1920s, the initial organizational stage was over for farmers' elevators; terminal markets, financial institutions, and the railroads generally treated them like other businesses. As a new generation of cooperators took control of the Rockwell Society and the other five hundred-plus farmers' elevators in Iowa, they also reaffirmed the slogan of the Iowa Farmers' Grain Dealers' Association: "A fair deal, stick together, pay your commissions, and when selling elsewhere, look out for the weights. ${ }^{\prime 2}$

41. Ibid., 27-28; Reeves v. Decorah Farmers' Co-operative Society, 160 Iowa Reports 194-206 (1913); American Cooperative Journal 8 (November 1912), 730.

42. Nourse, "Fifty Years of Farmers' Elevators," 252-59; Reeves Hall, "The Rockwell Cooperative," Palimpsest 24 (1943), 127. 
THE COOPERATIVE ELEVATOR CONCEPT and the Rockwell Society's fame spread across the United States and to Europe. George L. McNutt, an economist of the early 1900s, studied the Rockwell Society and wrote, "If you are troubled by the economic and social problems of the present, if you want to renew your faith in triumphant democracy, if you want to see what common men can do in the face of the greatest obstacles, if you want to believe in the social and economic redemption of the world, ask the conductor of the Iowa Central Railway to put you off at Rockwell, Iowa." The cooperative movement even caught the eye of Theodore Roosevelt, who affirmed in 1909 that "the cooperative plan is the best plan of organization wherever men have the right spirit to carry it out." ${ }^{143}$

Why, then, did the Rockwell Society and the other Iowa farmers' elevators that modeled themselves on it succeed? Perhaps most importantly, cooperatives of the late nineteenth century developed a relatively clear view of who their allies and enemies were. They took a common-sense approach to the conflict, realizing that only in collective action did they have a chance for victory. Farmers' cooperatives prized merit and knowledge; "clanishness, politics, religion, nationality were kept in the background." The "one man, one vote" rule caught on early and provided a much needed democratic consciousness. They were also determined to achieve success by scrupulously direct and honest means, which helped to convert their movement into something of a righteous cause. Cooperative societies maintained open books and records, which any member could examine. Most of those involved in farmers' elevators believed that cooperation made good people, good citizens, and good Christians. They were devoted to cooperation and their elevators because they believed that these were paths to improved rural life. ${ }^{44}$

In part, an abundance of excellent cooperative elevator directors and managers helped bring to fruition an organiza-

43. McNutt and Roosevelt quoted in Hall, "Rockwell Cooperative," 128.

44. McManus, "Rockwell Co-operative Society," 369. For the idealism surrounding the Granger version of cooperation, see William Cronon, Nature's Metropolis: Chicago and the Great West (New York, 1991), 359-64. 
tional system that reflected the farmers' vision of fairness, equality, dignity, and democracy. They believed in the inherent nobility of their cause; they perceived their struggle as the good fight. One of the foremost northern Iowa cooperators, Thomas McManus, expressed his feelings this way: "The time spent, and the associations formed in the cooperative movement have been among the happiest days of my life, and if I should live to an age when my steps shall begin to totter, and my hair whitened with the frosts of many winters, I shall always look back with personal pride on my feeble efforts in doing the very best I could in promoting its ultimate success. ${ }^{145}$

In historical perspective, the Rockwell Society, the farmers' elevator movement, and its concomitant circumstances of agrarian protest represented more than a mere episode of adjustment to a changing economy or reaction to new social forces. The Iowans who supported it participated in the phenomenon that Lawrence Goodwyn calls "the Populist moment" by daring to stand against powerful business and economic interests in the nineteenth-century grain trade. Iowa farmers gave only qualified and sometimes marginal support to populist or radical farm organizations, but the farmers' elevator movement achieved many of the same goals. Cooperative elevators also represented creative responses to changing technologies, commercial organizations, and the general economic structure of American society. For many of the true believers in the cooperative movement, the Rockwell Society and the farmers' elevator movement ultimately became symbols not only of resistance to hegemonic economic forces, but also instruments of social and political empowerment, if only on a local and regional level.

45. McManus, "Rockwell Co-operative Society," 372. 
Copyright of Annals of Iowa is the property of State of Iowa, by \& through the State Historical Society of Iowa and its content may not be copied or emailed to multiple sites or posted to a listserv without the copyright holder's express written permission. However, users may print, download, or email articles for individual use. 